\title{
EFFECT OF CARNATIC VOCAL MUSIC TRAINING AND EXPERIENCE ON CORTICAL AUDITORY EVOKED POTENTIALS
}

\author{
Himanshu Kumar Sanju, J. Nikhil, Prawin Kumar \\ Department of Audiology, All India Institute of Speech and Hearing, Mysore, India
}

Corresponding author: Himanshu Kumar Sanju, Department of Audiology, All India Institute of Speech and Hearing, Mysore, India, e-mail: himanshusanjuaiish@gmail.com

\begin{abstract}
Background: A musician's ability to produce a precise pitch must involve some kind of neuroplasticity, allowing them to control fundamental frequency, maintain target pitch, and accurately control pitch through auditory perceptual monitoring. The present study uses cortical auditory evoked potentials (CAEPs) to investigate neuroplasticity by assessing the latency of P1, $\mathrm{N} 1, \mathrm{P} 2$, and $\mathrm{N} 2$ as well as the peak-to-peak amplitudes P1-N1, N1-P2, and P2-N2 in two groups of subjects: Carnatic vocal musicians and non-musicians.
\end{abstract}

Materials and methods: Two groups of normal hearing females aged 18 to 25 years. There were 20 Carnatic vocal musicians (Indian classical music of south India) and 20 non-musicians. Pure tones were used as stimuli.

Results: Descriptive statistics revealed lower latency and greater peak-to-peak amplitude for all measures in the Carnatic vocal musicians compared to the non-musicians. MANOVA showed that vocalists had significantly better (shorter) N1, P2, and N2 latencies and significantly better (greater) peak-to-peak amplitude of P1-N1.

Conclusions: The present study showed some significantly enhanced CAEP parameters in Carnatic vocal musicians compared to non-musicians. This indicates that musical experience has an effect on the central auditory nervous system, and this form of neuroplasticity can be investigated with CAEPs.

Keywords: auditory evoked potentials $\bullet$ music $\bullet$ neuronal plasticity

\section{IMPACTO Y EXPERIENCIAS EN EL APRENDIZAJE DEL CANTO CARNÁTICO EN LOS POTENCIALES AUDITIVOS CORTICALES}

\section{Resumen}

Introducción: Las habilidades de los músicos de obtener los tonos de voz apropiados, están asociados con cierta neuroplasticidad, que permite controlar las frecuencias fundamentales, mantener un tono de destino y un control apropiado de tono mediante el control perceptivo del oído. El presente estudio utiliza los potenciales auditivos evocados (CAEP) para estudiar la neuroplasticidad mediante la evaluación de la latencia P1, N2, P2 y N2, así como la amplitud entre las cimas P1-N1, N1-P2, y P2-N2 en dos grupos temáticos: cantantes de las canciones carnáticas y las personas que no son músicos.

Materiales y métodos: Dos grupos de mujeres con audición normal, de 18 a 25 años. 20 cantantes de canciones carnáticas (música clásica del sur de la India) y 20 personas que no son músicos. Incentivos utilizados en la forma de tonos.

Resultados: Las estadísticas descriptivas han demostrado una latencia menor y una amplitud mayor entre las cimas para todas las mediciones de cantantes de canciones carnáticas, en comparación con personas que no son músicos. MANOVA ha demostrado, que las cantantes tenían significativamente mejores (más cortas) latencias N1, P2 y N2 y una amplitud entre las cimas P1-N1 significativamente mejor (más amplia).

Conclusiones: El presente estudio ha demostrado unos parámetros CAEP significativamente reforzados en las cantantes de canciones carnáticas, en comparación con mujeres no-músicos. Este demuestra que la experiencia musical tiene impacto en las zonas auditivas del sistema nervioso central y este área de la neuroplasticidad puede ser examinada mediante los CAEP.

Palabras clave: potenciales auditivos evocados • música • neuroplasticidad 


\section{ВЛИЯНИЕ И ОПЫТ В ИЗУЧЕНИИ КАРНАТИК ВОКАЛА НА СЛУХОВЫЕ КОРКОВЫЕ ПОТЕНЦИАЛЫ}

\section{Изложение}

Введение: Способности музыкантов получения соответствующего тембра голоса связаны с определенной нейропластичностью, позволяющей контролировать элементарные частоты, удержать определенный тембр и соответствующим образом контролировать тембр путем перцептивного мониторинга слуха. Настоящее исследование использует слуховые вызванные потенциалы (САЕР) для исследования нейропластичности путем оценки латенции P1, N1, P2 и N2, а также амплитуды полного размаха P1-N1, N1-P2 и P2-N2 в двух тематических группах: вокалистов песен карнатик и людей, которые не являются музыкантами.

Материал и методы: Две группы женщин с нормальным слухом в возрасте 18-25 лет. 20 вокалисток произведений карнатик (классическая музыка южной Индии) и 20 человек, не являющихся музыкантами. Использованы импульсы в форме тонов.

Результаты: Описательная статистика показала низшую латенцию и большую амплитуду полного размаха для всех измерений у солисток произведений карнатик в сравнении с людьми, не являющимися музыкантами. MANOVA показала, что вокалистки имели значительно лучшие (коротшие) латенции N1, P2 и N2 и значительно лучшую (большую) амплитуду полного размаха P1-N1.

Итоги: Настоящее исследование показало значительно усиленные параметры САЕР у вокалисток произведений карнатик в сравнении с женщинами, которые не являлись музыкантами. Это доказывает, что музыкальный опыт имеет влияние на слуховые зоны центральной нервной системы и эта зона нейропластичности может быть исследована с помощью САЕР.

Ключевые слова: слуховые вызванные потенцивлы • музыка • нейропластичность

\section{WPŁYW I DOŚWIADCZENIA W NAUCE ŚPIEWU KARNATYCKIEGO NA SŁUCHOWE POTENCJAŁY KOROWE}

\section{Streszczenie}

Wprowadzenie: Umiejętności muzyków uzyskiwania odpowiedniej tonacji głosu wiążą się z pewną neuroplastycznością, pozwalając na kontrolę podstawowych częstotliwości, utrzymania docelowej tonacji i odpowiedniej kontroli tonacji poprzez percepcyjne monitorowanie słuchu. Niniejsze badanie wykorzystuje słuchowe potencjały wywołane (CAEP) do badania neuroplastyczności poprzez ocenę latencji P1, N1, P2 i N2 jak również amplitudy międzyszczytowej P1-N1, N1-P2 i P2-N2 w dwóch grupach tematycznych: wokalistów piosenek karnatyckich i osób nie będących muzykami.

Materiał i metody: Dwie grupy kobiet z normalnym słuchem w wieku 18-25 lat. 20 wokalistek utworów karnatyckich (muzyka klasyczna Indii południowych) i 20 osób nie będących muzykami. Zastosowano bodźce w postaci tonów.

Wyniki: Statystki opisowe wskazały niższą latencję i większą amplitudę międzyszczytową dla wszystkich pomiarów u wokalistek utworów karnatyckich w porównaniu z osobami nie będącymi muzykami. MANOVA pokazała, że wokalistki miały znacząco lepsze (krótsze) latencje N1, P2 i N2 i znacznie lepszą (większą) amplitudę międzyszczytową P1-N1.

Wnioski: Niniejsze badanie wykazało znacząco wzmocnione parametry CAEP u wokalistek utworów karnatyckich w porównaniu z kobietami, które nie są muzykami. Dowodzi to, że doświadczenie muzyczne ma wpływ na obszary słuchowe ośrodkowego układu nerwowego i ten obszar neuroplastyczności może zostać zbadany przy pomocy CAEP.

Słowa kluczowe: słuchowe potencjały wywołane • muzyka • neuroplastyczność

\section{Background}

Cortical auditory evoked potentials (CAEPs) are non-invasive measures of acoustically evoked potentials. They are a component of the electroencephalogram (EEG) reflecting long-term neuroplastic changes. CAEPs have long laten$c y$, and can help assess central auditory system function.
Using CAEPs it is possible to track the maturation of the human brain through changes in latency, amplitude, and morphology [1]. Based on latency measures, CAEPs can be divided into four waves in the range 80 to $300 \mathrm{~ms}$ : a positive peak (P1) at about $50 \mathrm{~ms}$ followed by a large negative peak (N1) at $80-100 \mathrm{~ms}$, and a second positive peak (P2) at $180-200 \mathrm{~ms}$ followed by a negative peak (N2) at 
220-270 ms [2]. There are several factors on which the morphology of CAEP waveforms depend: age [3], attention [4], sleep state [5], presentation parameter [6], and electrode recording position $[7,8]$. CAEPs are generated by multiple temporally overlapping subcortical and cortical sources $[9,10]$; since these components are passively elicited, the subject does not need to perform a task and is simply asked to remain alert.

Changes in the morphology of the CEAP waveform, evident as changes in latency and amplitude, are considered to indicate increases in neural synchrony and strengthened neural connections [11]. P1 appears to arise from the primary auditory cortex, specifically Heschl's gyri, but may have contributions from thalamic and auditory association areas as well [12]. N1 has multiple, spatially distributed cortical sources which temporally overlap. These sources include Heschel's gyri, planum temporale, cingulate gyri, and auditory association areas in the lateral temporal and parietal lobes [13]. P2 appears to have multiple generators in primary auditory cortex: within the temporal lobe $[14,15]$, Heschl's gyrus, and primary auditory cortex within the Sylvian fissure [16]. Possible generators of $\mathrm{N} 2$ are the frontal lobe, limbic system, or other subcortical structures $[17,18]$.

A study by Shahin et al. in 2003 [19] showed that the P2 and N1c components of the auditory evoked potential (AEP) are sensitive to remodeling of the auditory cortex due to training (neuroplasticity). The term neuroplasticity refers to changes in the central nervous system as a result of experience or adaptation to environmental demands. Neuroplasticity can arise from changes in structure or function at either the cellular or system level. Modification of the gross anatomy of the brain, structural changes in individual brain cells, and reorganization of the neural network that subserve complex cognitive processes are all examples of neuroplasticity.

Music is a demanding cognitive and neural task which requires very accurate timing of multiple actions, precise control of pitch intervals not involved in language, and multiple ways of producing sound. Enhanced auditory perception in musicians is likely to result from auditory perceptual learning over several years of training. Auditory perceptual learning is a term referring to improvements in the auditory system's ability to discriminate differences in certain attributes of a stimulus. In 2014, Polat and Atas used CAEP and speech stimuli on young adult musicians to show that musical experience has an effect on the nervous system [20]. Similarly, Shahin et al. (2003) reported that highly skilled violinists and pianists showed larger N1c (latency of $138 \mathrm{~ms}$ ) and P2 (latency of $185 \mathrm{~ms}$ ) responses to tonal stimuli [19]. In 2004, Shahin et al. played violin and piano tones to 4 - and 5-year-old pianists and violinists and found enhancement of P2 after practice [21]. Similar findings were seen by Trainer and colleagues in 2003 from studying auditory evoked potentials (evoked by pure tones, violin tones, and piano tones) in adult and child musicians. The results showed that the $\mathrm{P} 2$ response was enhanced in both adult and child musicians, but not in non-musicians, and that auditory training could enhance this component in non-musician adults [22].
In the case of vocal singers, control of pitch is a complex biomechanical and aerodynamic system, and their ability to produce a precise pitch is crucial. The literature shows that accurate pitch control depends on auditory perceptual monitoring and proprioceptive feedback of the laryngeal and phonatory reflex systems [23-25]. Nikjeh et al. (2008) investigated mismatch negativity (MMN) among 61 subjects which included 20 vocalists, 21 instrumentalists, and 20 non-musicians. MMN was evoked by a multi-deviant paradigm and the stimuli were harmonic tone complexes from the female mid-vocal range (C4-G4). The results showed that, compared to non-musicians, both vocal and instrumental musicians had an enhanced skill for pre-attentive auditory discrimination of acoustic parameters [26]. Professional vocalists consistently controlled the fundamental frequency and maintained target pitch better than did non-singers.

There must therefore have been a neuroplastic change in the musicians. Better auditory perceptual monitoring arose simultaneously with accurate control of fundamental frequency, target pitch, and pitch. Previously, CAEPs investigated on western classical musicians have shown enhanced CAEP responses [19-21]. However, there are some fundamental mechanistic differences between Indian and Western classical music in terms of pitch structure and temporal patterning. Some basic elements of Indian music - e.g. taala (the rhythmic pattern), shruti (the relative musical pitch), raaga (the melodic mode), and swara (the musical sound of a single note) - are rarely found in western classical music. For the western listener, these characteristic features are difficult to appreciate without special training. Recent behavioral tests on Indian classical musicians has found enhanced auditory skills [27-31]. It is therefore interesting to know whether Indian classical music training and practice has an effect on CAEPs. Since there is a general lack of literature on CAEP in Carnatic vocal musicians, the aim of the present study was to assess $\mathrm{P} 1, \mathrm{~N} 1$, $\mathrm{P} 2$, and $\mathrm{N} 2$ latency, as well as $\mathrm{P} 1-\mathrm{N} 1, \mathrm{~N} 1-\mathrm{P} 2$, and $\mathrm{P} 2-\mathrm{N} 2$ peak-to-peak amplitude, in Carnatic vocal musicians (Indian classical music of south India) and compare the results with those from non-musicians.

\section{Materials and methods}

\section{Participants}

Two groups of subjects (females only) aged 18 to 25 years participated. There were 20 in an experimental group (mean age $21.05 \pm 1.79$ ) and 20 in a control group (mean age $20.12 \pm 1.53$ years). The experimental group comprised subjects who had a minimum professional experience of 5 years of Carnatic vocal music exposure (Indian classical music of south India). On average, they practised $18.3 \pm 10.3$ hours per week and had 7.7 years of experience; all had started their musical training after the age of 11 years. Subjects who practised music other than Carnatic vocal music were strictly excluded from the study. Agematched participants from a private arts college who did not have any formal training in music served as a non-musician control group. Informed written consent was taken from all participants, and the study was approved by the ethical committee at the All India Institute of Speech and Hearing, Mysore. 


\section{Participant selection criteria}

All the participants had normal hearing thresholds as defined by pure tone thresholds of $<15 \mathrm{dBHL}$ at 250,500 , 1000, 2000, 4000, and $8000 \mathrm{~Hz}$. Further, they did not have any middle ear pathology as revealed by a middle ear analyzer. Subjects who had any other otological, neuromuscular, or neurological problem were excluded from the study.

\section{Testing environment}

Electrophysiological tests were carried out in a soundtreated room where noise levels were as per the guidelines in ANSI S3.1 (1991). The test room was well illuminated and air-conditioned.

\section{Instrumentation}

A calibrated two-channel clinical audiometer (Orbitor 922) was used for pure tone audiometry, and a calibrated GSITympstar immittance meter was be used for tympanometry and acoustic reflex threshold testing. An Intelligent Hearing System with smart EP was used to record CAEPs.

\section{Procedure}

Pure tone thresholds were obtained using a modified version of the Hughson and Westlake procedure (Carhart \& Jerger, 1959) across frequencies of 250, 500, 1000, 2000, 4000 , and $8000 \mathrm{~Hz}$ for air conduction and of 500,1000, 2000, and $4000 \mathrm{~Hz}$ for bone conduction [32]. A middle ear analyzer was used to carry out tympanometry using a probe tone of $226 \mathrm{~Hz}$ and to obtain ipsilateral and contralateral acoustic reflexes thresholds at 500, 1000, 2000, and $4000 \mathrm{~Hz}$.

Electrophysiological testing included click-evoked ABR to verify the normal hearing sensitivity of participants when required. For ABR recording, the subject was seated in a reclining chair. The skin surface at the two mastoids (M1, $\mathrm{M} 2$ ) and forehead (Fz) was cleaned with skin abrasive to obtain a skin impedance of less than $5 \mathrm{k} \Omega$ for all electrodes. The electrodes were placed with the help of skin conduction paste and surgical plaster was used to secure them in place. To minimize artifacts, participants were instructed to relax and refrain from extraneous body movements.

CAEPs were recorded using an Intelligent Hearing System with smart EP in a sound-treated room. The stimulus was a $1000 \mathrm{~Hz}$ pure tone with $30 \mathrm{~ms}$ rise/fall times and $140 \mathrm{~ms}$ plateau. CAEPs were recorded in a vertical montage with $\mathrm{Cz}$ as the positive electrode referenced to the nape of the neck. The ground electrode was placed on the lower forehead. A second channel was used to record eye-blink responses. Sweeps with large eye-blink artifacts were eliminated from averaging. Stimuli were presented at $70 \mathrm{dBnHL}$ in rarefaction polarity at a repetition rate of $1.1 / \mathrm{sec}$. The responses were averaged for 400 sweeps over -50 to 500 $\mathrm{ms}$ with reference to stimulus onset. The filter was set to a bandpass of 1 to $30 \mathrm{~Hz}$ and amplified 50,000 times. Stimuli were presented binaurally. Participants were seated comfortably in order to avoid muscular artifacts. The skin surface of the target electrode sites was cleaned and disc electrodes were placed. Recording started only if the impedance was less than $5 \mathrm{k} \Omega$ and inter-electrode impedance was less than $2 \mathrm{k} \Omega$. CAEPs were analyzed in terms of P1, N1, P2, and N2 latency as well as P1-N1, N1-P2, and $\mathrm{P} 2-\mathrm{N} 2$ peak-to-peak amplitude in vocal musicians and compared with non-musicians.

\section{Statistical analysis}

Descriptive statistics was done to find the mean and standard deviation (SD) for all measures of CAEP (latency of $\mathrm{P} 1, \mathrm{~N} 1, \mathrm{P} 2$, and $\mathrm{N} 2$ and amplitude of P1-N1, N1-P2, and $\mathrm{P} 2-\mathrm{N} 2)$. To reduce the chance of a type 1 error, MANOVA was also done using SPSS (v.17) to compare vocal musicians and non-musicians for each CAEP measure.

\section{Results}

The different CAEP measures (P1, N1, P2, and N2 latency and $\mathrm{P} 1-\mathrm{N} 1, \mathrm{~N} 1-\mathrm{P} 2$, and $\mathrm{P} 2-\mathrm{N} 2$ peak-to-peak amplitude) were noted through visual inspection for each participant. A Shapiro-Wilk test was used to check that the data for both groups followed a normal distribution. Descriptive statistics showing mean and SD of P1, N1, P2, and N2 latency are given in Table 1. Similar descriptive statistics for P1-N1, N1-P2, and P2-N2 peak-to-peak amplitude are given in Table 2. MANOVA was used to compare musicians and non-musicians for each CAEP measure. Sample waveforms of a CAEP for a musician and a non-musician are given in Figures 1 and 2 respectively.

\section{$\mathrm{P} 1, \mathrm{~N} 1, \mathrm{P} 2$, and N2 latency}

Descriptive statistics were done to find mean and SD for P1, N1, P2, and N2 latency for both the Carnatic vocal musicians and non-musicians. Table 1 lists the mean and SD of all latencies measured in musicians and non-musicians. It shows that Carnatic vocal musicians have shorter (better) latencies for all measures ( $11, \mathrm{~N} 1, \mathrm{P} 2, \mathrm{~N} 2)$ compared to non-musicians. It can also be seen that the SD was greater for non-musicians compared to musicians for all latency measures (P1, N1, P2, and N2). Figure 3 shows these results graphically.

MANOVA was carried out to find out if the latency differences between the Carnatic vocal musicians and nonmusicians were significant. Results showed that musicians have significantly better N1 latency $[F(1,38)=4.71 ; p<0.05$; $\left.\eta^{2}=0.11\right]$, P2 latency $\left[F(1,38)=19.14 ; p<0.05 ; \eta^{2}=0.33\right]$, and $\mathrm{N} 2$ latency $\left[F(1,38)=16.42 ; p<0.05 ; \eta^{2}=0.30\right]$. For P1 latency, MANOVA showed no significant difference between the groups $\left[F(1,38)=2.93 ; p>0.05 ; \eta^{2}=0.07\right]$.

\section{P1-N1, N1-P2, and P2-N2 peak-to-peak amplitude}

Descriptive statistics were calculated to find the mean and SD for P1-N1, N1-P2, and P2-N2 peak-to-peak amplitude for both groups. Table 2 shows that Carnatic vocal musicians have greater (better) peak-to-peak amplitude for P1-N1, N1-P2, and P2-N2 compared to non-musicians. Figure 4 plots these results, together with error bars.

MANOVA was carried out to test if amplitude differences between the groups were significant. MANOVA showed that musicians have significantly greater (better) 
Table 1. Mean and standard deviation (SD) of P1, N1, P2, and N2 latency for the vocal musicians and non-musicians

\begin{tabular}{ccccc}
\hline Groups & $\begin{array}{c}\text { P1 Latency (ms) } \\
\boldsymbol{F = 2 . 9 3 ;} \mathbf{p = 0 . 9 5} \\
\text { Mean (SD) }\end{array}$ & $\begin{array}{c}\text { N1 Latency (ms) } \\
\boldsymbol{F}=\mathbf{4 . 7 1 ;} \mathbf{p = 0 . 0 3} \\
\text { Mean (SD) }\end{array}$ & $\begin{array}{c}\text { P2 Latency (ms) } \\
\boldsymbol{F = 1 9 . 1 4 ;} \mathbf{p = 0 . 0 0} \\
\text { Mean (SD) }\end{array}$ & $\begin{array}{c}\text { N2 Latency (ms) } \\
\boldsymbol{F}=\mathbf{1 6 . 4 2 ;} \mathbf{p = 0 . 0 0} \\
\text { Mean (SD) }\end{array}$ \\
\hline Vocal musicians & $51.25(7.43)$ & $93.25(9.51)$ & $141.80(8.20)$ & $201.75(13.09)$ \\
\hline Non-musicians & $56.60(11.82)$ & $101.65(14.52)$ & $154.65(10.25)$ & $219.75(14.94)$ \\
\hline
\end{tabular}

Table 2. Mean and standard deviation (SD) of peak-to-peak amplitude of P1-N1, N1-P2, and P2-N2 for the vocal musicians and non-musicians

\begin{tabular}{|c|c|c|c|c|}
\hline Groups & $\begin{array}{c}\text { P1-N1 }(\mu v) \\
(F=6.96 ; p=0.01) \\
\text { Mean (SD) }\end{array}$ & $\begin{array}{c}\text { N1-P2 }(\mu v) \\
(F=2.12 ; p=0.15) \\
\text { Mean (SD) }\end{array}$ & $\begin{array}{r}\text { P2-I } \\
(F=1.68 \\
\text { Mea }\end{array}$ & $\begin{array}{l}2(\mu v) \\
; p=0.20) \\
n(S D)\end{array}$ \\
\hline Vocal musicians & $3.66 \quad(0.88)$ & $3.52 \quad(1.33)$ & 3.68 & (1.53) \\
\hline Non-musicians & $2.87 \quad(1.00)$ & $2.96 \quad(1.09)$ & 3.13 & (1.13) \\
\hline
\end{tabular}
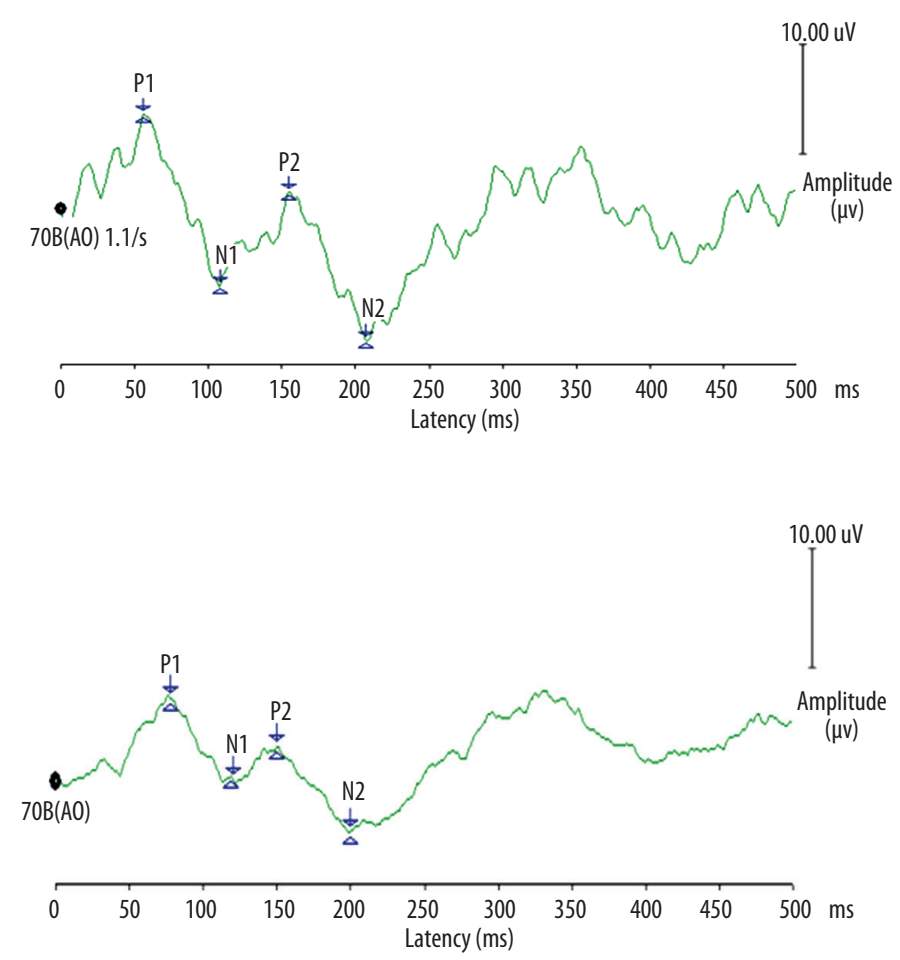

Figure 1. Sample waveform of cortical auditory evoked potential in a Carnatic vocal musician

Figure 2. Sample waveform of cortical auditory evoked potential in a non-musician peak-to-peak amplitude for $\mathrm{P} 1-\mathrm{N} 1[F(1,38)=6.96 ; p<0.05$; $\left.\eta^{2}=0.15\right]$. No significant differences were seen for N1-P2 $\left[\mathrm{F}(1,38)=2.12 ; p>0.05 ; \eta^{2}=0.05\right]$ and $\mathrm{P} 2-\mathrm{N} 2[\mathrm{~F}(1,38)=1.68$; $\left.p>0.05 ; \eta^{2}=0.04\right]$.

\section{Discussion}

The aim of the present study was to measure P1, N1, P2, and N2 latency as well as P1-N1, N1-P2, and P2-N2 peak-to-peak amplitude in Carnatic vocal musicians and compare them with those of non-musicians. Descriptive statistics showed that, for all measures, there were earlier (better) peak latencies and greater (better) peak-topeak amplitudes in Carnatic vocal musicians compared to non-musicians. However, MANOVA showed that the differences were significant only for N1, P2, and N2 latencies (where they were better in vocal musicians compared to non-musicians) and for P1-N1 peak-to-peak amplitude (where it was again better in Carnatic vocal musicians than in non-musicians).

In general, the results of the present study show there is distinct neural enhancement at the cortical level in Carnatic vocal musicians compared with non-musicians. For vocalists, the musical instrument is the larynx, the organ responsible for voice production. Enhanced auditory perception and vocal pitch control are both important skills for a vocalist. Vocal pitch control requires the integration of the body's motor and sensory systems. Regular vocal practice might fine-tune the cortical processing of auditory 


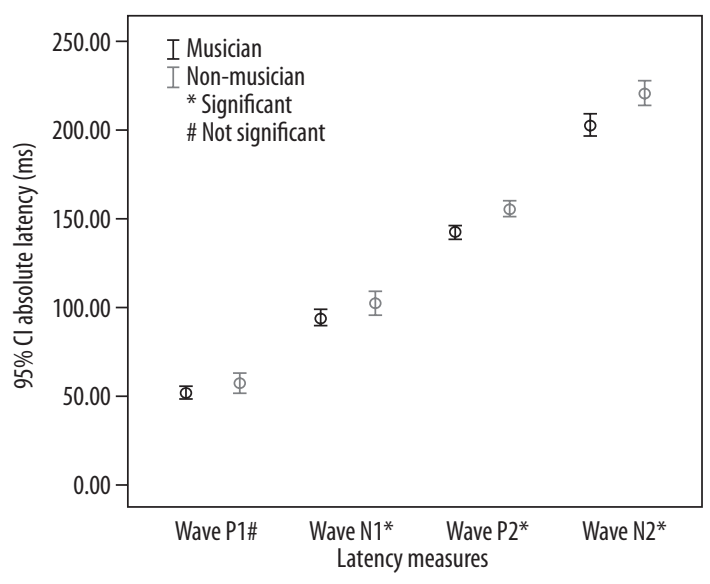

Figure 3. Latency measures for Carnatic vocal musicians and non-musicians. Error bars show standard deviations

stimuli, leading to enhanced CAEPs. The outcomes of the present study are consonant with previous investigations [19-22,33] on CAEPs among different types of musicians (violinists, pianists, vocalists, etc.) and with different types of stimuli (speech, pure tone, music, etc.).

Changes in the morphology of CEAP waveforms, measured as a decrease in latency or an increase in amplitude, are considered to indicate an increase in neural synchrony and strengthened neural connections [11]. Shahin et al. (2003) investigated whether an increase in neuroplasticity among musicians (violinists and pianists) matched their musical training histories. The results showed that, compared to non-musicians, the musician group had larger N1c and P2 responses to three types of tonal stimuli [19]. Similarly, Trainor et al. (2003) measured auditory evoked potentials in adult musicians and non-musicians, as well as in 4- and 5-year-old children who had extensive musical training, and compared them with children who had never had any musical training. The stimuli were piano tones, violin tones, and pure tones. The results showed that P2 was enhanced in both adult and child musicians compared to non-musicians, and that $\mathrm{P} 2$ reflected neuroplasticity and the effect of early musical training [33]. Using piano tones, violin tones, and pure tones as stimuli, Shahin et al. (2004) investigated N1 and P2 evoked responses in children enrolled in Suzuki music lessons. For all tones, P1 was larger in the Suzuki pupils compared to a control group of non-musicians, whereas P2 was enhanced only for the instrument of practice (piano or violin). In pianists, it was also observed that although the P2 amplitude increased with spectral complexity, N1 amplitude did not [21]. The outcome of the present study is in consonance with the study done by Shahin et al. (2004). Similar to their results, the present study also found significantly better P1-N1 peak-to-peak amplitudes evoked by tonal stimuli among Carnatic vocal musicians compared to non-musicians.

Musachhia et al. (2008) investigated cortical encoding of speech in 26 participants. It was seen that overall P1 and N1 peaks were earlier in latency and larger in amplitude for musicians [33]. Using speech stimuli, Polat and

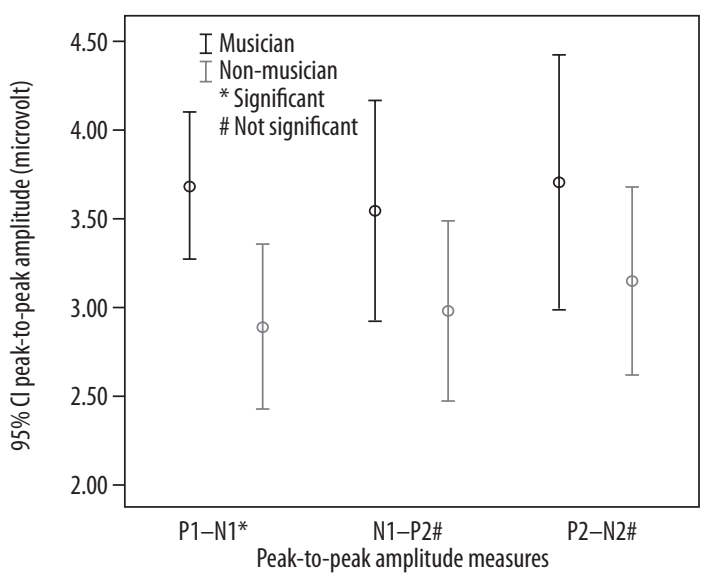

Figure 4. Peak-to-peak amplitude of P1-N1, N1-P2, and P2-N2 for Carnatic vocal musicians and non-musicians. Error bars show standard deviations

Atas (2014) investigated CAEPs and reported significantly greater amplitudes of P1 and P2 in young adult musicians compared to non-musicians [20]; they also found decreases in latency. While our finding of an amplitude increase is similar, the latency decrease is in contrast with our present findings which revealed no significant difference in latencies between musicians and non-musicians, a disparity that might be due to a difference in the stimuli used, i.e. tones vs. speech [20]. Although the present study found superior CAEPs in vocal musicians compared to non-musicians, it failed to show any significant difference for P1 latency, N1-P2, and P2-N2 peak-to-peak amplitude, and this is not unlike the results of Shahin et al. (2003) [19], who failed to find any significant difference for N1 amplitude. This aspect of our findings concurs with the aforementioned EEG studies, which also failed to show enhanced N1 responses after training for spectral or temporal acoustic discrimination [34,35].

A study by Sharma et al. [36] on the measurement of intervention outcomes in children with central auditory processing disorder also failed to report a significant difference between the control group and study group in terms of P1 latency, although a significant difference was seen for P1 amplitude, which generally supports our study's findings. In terms of P1 latency, Poton et al. [13] noted that it is adult-like by age 10, whereas other peaks mature later in life. According to Poton and colleagues, this difference in maturational time may account for P1 being relatively resistant to the effect of noise. The current study has found that Carnatic vocal musical experience has an effect on the central auditory nervous system, and this can be seen in CAEPs recorded with tonal stimuli. In future, the present study will be replicated with speech stimuli to obtain a clearer idea about the cortical processing of speech in vocal musicians.

\section{Conclusions}

The present study has shown that vocal musical training and experience enhances a person's CAEPs. Carnatic vocal training and experience promotes neuroplasticity at the 
cortical level, findings which can be used to track the progress of rehabilitation through musical training. In particular, there are clinical populations who have generally poor CAEPs - i.e. those with central auditory processing disorder, learning disability, Parkinson's disease, schizophrenia, Alzheimer's disease, children with developmental language disorder, children with cochlear implant, and phonological disorder [37-40]. Vocal music training in these populations might lead to enhancement in neuroplasticity, eventually providing better speech perception and communication skills.

\section{Acknowledgements}

The Director of AIISH gave permission to carry out this study and the HOD of the Department of Audiology provided instrumentation. We thank Ms Priyanka Mohan (graduate student at AIISH) for her help during preparation of the manuscript. We are grateful to Mrs Geeta Kumari Singh for motivation and support during data collection and manuscript preparation. Finally, we thank all the participants.

\section{References:}

1. Eggermont JJ. On the rate of maturation of sensory evoked potentials. Electroencephalogr Clin Neurophysiol, 1988; 70: 293-305.

2. Oates PA, Kurtzberg D, Stapells DR. Effects of sensorineural hearing loss on cortical event-related potential and behavioral measures of speech-sound processing. Ear Hear, 2002; 23: 399-415.

3. Wunderlich JL, Cone-Wesson BK, Shepherd R. Maturation of the cortical auditory evoked potential in infants and young children. Hear Res, 2006; 212: 185-202.

4. Picton TW, Hillyard SA. Human auditory evoked potentials. II. Effects of attention. Electroencephalogr Clin Neurophysiol, 1974; 36: 191-99.

5. Mendel MI, Hosick EC, Windman TR, Davis H, Hirsh SK, Dinges DF. Audiometric comparison of the middle and late components of the adult auditory evoked potentials awake and asleep. Electroencephalogr Clin Neurophysiol, 1975; 38: 27-33.

6. Golding M, Pearce W, Seymour J, Cooper A, Ching T, Dillon $\mathrm{H}$. The relationship between obligatory cortical auditory evoked potentials (CAEPs) and functional measures in young infants. J Am Acad Audiol, 2007; 18: 117-25.

7. Novak GP, Kurtzberg D, Kreuzer JA, Vaughan HG. Cortical responses to speech sounds and their formants in normal infants: maturational sequence and spatiotemporal analysis. Electroencephalogr Clin Neurophysiol, 1989; 73: 295-305.

8. Pang EW, Taylor MJ. Tracking the development of the N1 from age 3 to adulthood: An examination of speech and non-speech stimuli. Clin Neurophysiol, 2000; 111: 388-97.

9. Chen BM, Buchwald JS. Midlatency auditory evoked responses: Differential effects of sleep in the cat. Electroencephalogr Clin Neurophysiol, 1986; 65: 373-82.

10. Näätänen R, Picton T. The N1 wave of the human electric and magnetic response to sound: A review and an analysis of the component structure. Psychophysiol, 1987; 24: 375-425.

11. Tremblay K, Kraus N, McGee T, Ponton C, Otis B. Central auditory plasticity: Changes in the N1-P2 complex after speechsound training. Ear Hear, 2001; 22: 79-90.

12. Buchwald JS, Erwin R, Van Lancker D, Guthrie D, Schwafel J, Tanguay P. Midlatency auditory evoked responses: P1 abnormalities in adult autistic subjects. Electroencephalogr Clin Neurophysiol, 1992; 84: 164-71.

13. Ponton CW, Eggermont JJ. Of kittens and kids: Altered cortical maturation following profound deafness and cochlear implant use. Audiol Neurootol, 2001; 6: 363-80.

14. Hari R, Hämäläinen M, Ilmoniemi R, Kaukoranta E, Reinikainen K, Salminen J et al. Responses of the primary auditory cortex to pitch changes in a sequence of tone pips: Neuromagnetic recordings in man. Neurosci Lett, 1984; 50: 127-32.
15. Vaughan HG, Ritter W. The sources of auditory evoked responses recorded from the human scalp. Electroencephalogr Clin Neurophysiol, 1970; 28: 360-67.

16. Crowley KE, Colrain IM. A review of the evidence for P2 being an independent component process: Age, sleep and modality. Clin Neurophysiol, 2004; 115: 732-44.

17. Kiehl KA, Smith AM, Hare RD, Mendrek A, Forster BB, Brink $\mathrm{J}$ et al. Limbic abnormalities in affective processing by criminal psychopaths as revealed by functional magnetic resonance imaging. Biol Psychiatry, 2001; 50: 677-84.

18. Näätänen R. Processing negativity: An evoked-potential reflection of selective attention. Psychol Bull, 1982; 92: 605-40.

19. Shahin A, Bosnyak DJ, Trainor LJ, Roberts LE. Enhancement of neuroplastic $\mathrm{P} 2$ and N1c auditory evoked potentials in musicians. J Neurosci, 2003; 23: 5545-52.

20. Polat Z, Ataş A. The investigation of cortical auditory evoked potentials responses in young adults having musical education. Balkan Med J, 2014; 31: 328-34.

21. Shahin A, Roberts LE, Trainor LJ. Enhancement of auditory cortical development by musical experience in children. Neuroreport, 2004; 15: 1917-21.

22. Amir O, Amir N, Kishon-Rabin L. The effect of superior auditory skills on vocal accuracy. J Acoust Soc Am, 2003; 113: $1102-8$.

23. Jones JA, Munhall KG. Perceptual calibration of F0 production: evidence from feedback perturbation. J Acoust Soc Am, 2000; 108: 1246-51.

24. Mürbe D, Pabst F, Hofmann G, Sundberg J. Effects of a professional solo singer education on auditory and kinesthetic feedback: A longitudinal study of singers' pitch control. J Voice, 2004; 18: 236-41.

25. Carhart R, Jerger J. Preferred method for clinical determination of pure-tone thresholds. J Speech Hear Disord, 1959; 24: 330-35.

26. Nikjeh DA, Lister JJ, Frisch SA. Hearing of note: An electrophysiologic and psychoacoustic comparison of pitch discrimination between vocal and instrumental musicians. Psychophysiol, 2008; 45: 994-1007.

27. Sangamanatha AV, Fernandes J, Bhat J, Srivastava M, Prakrithi SU. Temporal resolution in individuals with and without musical training. J Ind Sp Hear Assoc, 2001; 26: 27-35.

28. Mishra SK, Panda MR. Experience-dependent learning of auditory temporal resolution: Evidence from Carnatic-trained musicians. Neuroreport, 2014; 25: 134-37.

29. Mishra SK, Panda MR, Raj S. Influence of musical training on sensitivity to temporal fine structure. Int J Audiol, 2015; 54: $220-26$. 
30. Kumar P, Sanju HK, Nikhil J. Temporal resolution and active auditory discrimination skill in vocal musicians. Int Arch Otorhinolaryngol, 2015 (early online, $\mathrm{ms}$ in press).

31. Sanju HK, Kumar P. Research suggests new avenues for music training in aural rehabilitation. Hear Rev, 2015; 22: 34.

32. Musacchia G, Strait D, Kraus N. Relationships between behavior, brainstem and cortical encoding of seen and heard speech in musicians and non-musicians. Hear Res, 2008; 241: 34-42.

33. Trainor LJ, Shahin A, Roberts LE. Effects of musical training on the auditory cortex in children. Ann NY Acad Sci, 2003; 999: 506-13.

34. Tremblay K, Kraus N, McGee T, Ponton C, Otis B. Central auditory plasticity: Changes in the N1-P2 complex after speechsound training. Ear Hear, 2001; 22: 79-90.

35. Atienza M, Cantero JL, Dominguez-Marin E. The time course of neural changes underlying auditory perceptual learning. Learn Mem, 2002; 9: 138-50.
36. Sharma M, Purdy SC, Kelly AS. The contribution of speechevoked cortical auditory evoked potentials to the diagnosis and measurement of intervention outcomes in children with auditory processing disorder. Semin Hear, 2014; 35: 51-64.

37. Pfefferbaum A, Horvath TB, Roth WT, Tinklenberg JR, Kopell BS. Auditory brain stem and cortical evoked potentials in schizophrenia. Biol Psychiatry, 1980; 15: 209-23

38. Bruneau N, Roux S, Adrien JL, Barthélémy C. Auditory associative cortex dysfunction in children with autism: Evidence from late auditory evoked potentials (N1 wave- $\mathrm{T}$ complex). Clin Neurophysiol, 1999; 110: 1927-34.

39. Purdy KS, Mcmullen PA, Freedman M. Changes to the object recognition system in patients with dementia of the Alzheimer's type. Brain Cogn, 2002; 49: 213-16.

40. Leite RA, Wertzner HF, Matas CG. Long latency auditory evoked potentials in children with phonological disorder. Pro Fono, 2010; 22: 561-66. 